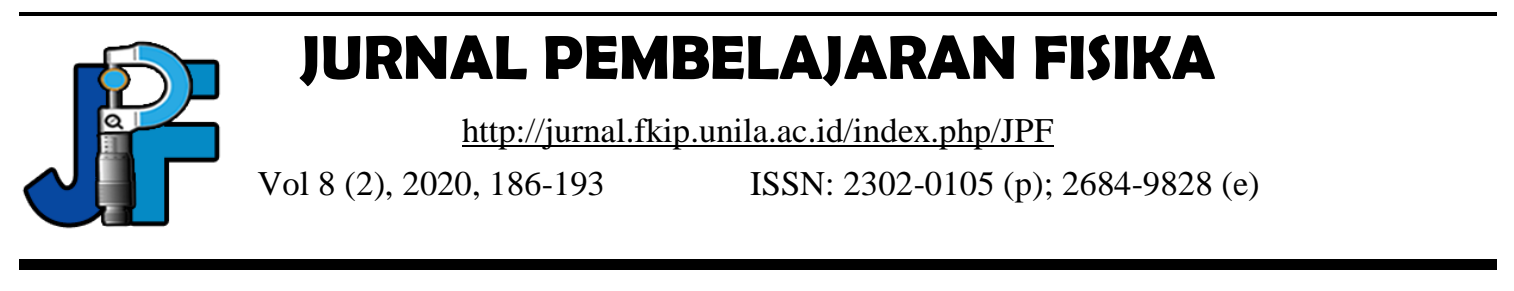

\title{
The Effectiveness of Video-Based POE2WE Model on Magnetic Induction Materials in the COVID 19 Pandemic
}

\author{
Fifi Aprilia*, Nana, Dwi Sulistyaningsih \\ Siliwangi University, Indonesia \\ *e-mail: apriliafifi3@gmail.com
}

\begin{abstract}
This study aims to determine the effectiveness of the POE2WE model in learning, determine the effectiveness of using video in learning, determine the effectiveness of the videobased POE2WE model in learning, and determine the level of understanding of the research object. The research method used is a quantitative method in the form of a the survey. The quantitative method is a scientific research method whose data is in the form of numbers or statistics. Meanwhile, survey is a technique of collecting data about a population using a sample. The objects in the study were 57 students of the Siliwangi University Physics Education class of 2018. The results of the study showed that the video-based learning model on magnetic induction material was effective in the pandemic.
\end{abstract}

Keywords: POE2WE model, learning videos, and pandemic period

DOI: http://dx.doi.org/10.23960/jpf.v8.n2.202007 


\section{INTRODUCTION}

The existence of the Covid-19 virus has had an impact on various aspects of life such as health, economy, social and education. In Indonesia, various efforts have been made to prevent the transmission of Covid 19, such as implementing social distancing, using masks and using hand sanitizers or washing hands in running water. With this policy, many aspects of social life have changed. In the world of education, learning is still being carried out, the education system is changed to online or online. . The impact of the spread of Covid-19 is now starting to enter the world of education. Educational institutions are expected not to carry out their usual activities; this is expected to reduce the spread of Covid-19 (Abidah, 2020).

Even though the education system has changed a lot, learning success is still a goal in the world of education. Learning success is not only determined by students, but also by the teacher. The success of the teacher in delivering material really depends on the smooth interaction of communication between the teacher and students (Asnawir, 2002).

To support smooth communication. Teachers, students, and students are required to be able to use digital technology in the learning process. Digital technology is a solution to today's learning. Digital technology can connect students with teachers or students with lecturers and carry out learning. There are many ways to do learning. One way is to use video.

Video is a moving image resulting from a technological device. Instructional videos are common today. The use of technology in learning has led to a variety of learning media that are increasingly sophisticated and integrated with computers, such as films, videos, electronic distribution systems, books and printed media, audio media, multimedia, and interactive videos (Hosnan, 2014). The use and utilization of learning tools and media for the application of the results of this technology is aimed at increasing the effectiveness and efficiency of learning (Nurdin, 2017).

With the 21 st century learning skills, students are required to be able to find information from various references, by means of observation, so that students are able to solve their own problems based on the facts that have been found during observation. (Tarissa, 2018)

Apart from learning media, another important aspect is the learning model. The POE2WE learning model which stands for Prediction (predicting), Observation (observation), Explanation (explaining), Elaboration (elaborating), Write (conclusion), and Evaluation (evaluating) is a learning model designed to enable students to think critically, communicate, collaborate, and be creative. This is directly proportional to $21 \mathrm{st}$ century skills, namely $4 \mathrm{C}$, critical thinking, communicative, collaborative and creative. Through the POEW learning model, students can think critically to provide predictions about problems raised by the teacher. Through observation, students are asked to make direct observations, namely conducting experiments. The combination of the POE and TTW learning models requires students to discuss the results of discussions and convey ideas orally and in writing that will make it easier for students to memorize and understand the material being studied. (Nana, et al, 2014)

Learning with the POE model is learning that uses 3 main steps, including: Predict or prediction, namely predicting what will happen, Observe or observation, namely 
proving predictions through observation and Explain or explanation, namely explaining what has been predicted and observed (Dhea, 2018 ).

TTW is a learning model that includes the process of thinking, speaking and writing. The application of this model begins thinking, namely by reading then processing the information based on what has been read. Next is to make notes about something that has been read. In this case, students combine the information they have obtained with the ideas they have and present the writing in their own language. The next stage is speaking. At this stage students discuss what has been read at the thinking stage. The last is the writing stage. At this stage students record the results of the discussion on the worksheets provided. Writing activity is a process of processing ideas, because after discussion it will generate ideas that will be made in writing (Suparya, 2018).

\section{METHOD}

The research method used by the author is a quantitative method in the form of a survey. The quantitative method is a scientific research method whose data is in the form of numbers or statistics. The quantitative research method is a method used to examine a population or a random sample, the data analysis in this method is statistical to test predetermined hypotheses (Sugiyono, 2013).

Quantitative research methods can be defined as a research method based on the philosophy of positivism, used for research on specific populations or samples, sampling techniques are generally randomized, data collection uses research instruments, data analysis is quantitative / statistical to test hypotheses. . which have been set. (Sugiyono, 2013). Meanwhile, survey is a technique of collecting data about a population using a sample. The survey used by researchers is a questionnaire. The questionnaire can be interpreted as something that contains questions with a standard structure, in this case the research situation and conditions cannot be manipulated by the researcher (Priyono, 2008).

\section{Research procedure}

This research procedure includes:

$\left.\left.\left.\left.\left.\sum \begin{array}{c}\text { determination } \\ \text { of the research } \\ \text { problem }\end{array}\right\rangle \begin{array}{c}\text { make } \\ \text { research } \\ \text { designs }\end{array}\right\rangle \begin{array}{c}\text { compile a } \\ \text { questionnaire }\end{array}\right\rangle \begin{array}{c}\text { determine } \\ \text { the sample }\end{array}\right\rangle \begin{array}{c}\text { retrieve } \\ \text { data }\end{array}\right\rangle$

Part 1: research procedures

\section{Population and Sample}

Source: author's document

The population is the whole of the research object that has certain characteristics to study and produce conclusions (Sugiyono, 2013). The population in this study were students of the Siliwangi University Physics Education class of 2018. 
The sample is a fraction of the number and characteristics possessed by the population (Sugiyono, 2013). The samples in this study were 57 students of Siliwangi University Physics Education class of 2018.

This sample size was determined using the Slovin formula (Janti, 2014), namely:

$$
n=\frac{N}{1+N e^{2}}
$$

Where :

$\mathrm{n}=$ Sample

$\mathrm{N}=$ Population

$\mathrm{e}=$ Tolerance percentage of accuracy of sampling errors that can still be tolerated.

Because the population is small, the value of $e=0.05$

From this formula, the calculation is obtained as below :

$n=\frac{N}{1+N e^{2}}$

$n=\frac{67}{1+67(0,05)^{2}}$

$n=\frac{67}{1+0,1675}$

$n=\frac{67}{1,1675}$

$n=57,3 \approx 57$

So that the number of samples obtained from 67 populations is 57 .

\section{Data Collection and Instruments}

This study uses a questionnaire as a medium for data collection. The questionnaire is a data collection technique from several questions or written statements to be answered by respondents (Sugiyono, 2013).

Before filling out the questionnaire, the correspondents first watched the instructional video on magnetic induction material using the POE2WE model. The questionnaire that the researchers made consisted of 2 parts. The first part regarding the identity of the correspondent is name and email address. And the second part contains research-related questions.

Table 1. Topics of the questionnaire questions

\begin{tabular}{cl}
\hline No. & \multicolumn{1}{c}{ Question Topic } \\
\hline 1. & The effectiveness of the POE2WE model in learning \\
2. & The effectiveness of using video in online learning \\
3. & The effectiveness of the video-based POE2WE model in online learning \\
4. & The level of understanding obtained after watching the instructional video on magnetic \\
induction material & Correspondent responses regarding the effectiveness of the POE2WE model and \\
learning videos
\end{tabular}




\section{Data Analysis}

The data obtained from this study is closely related to the problems faced, namely changes in the learning system. The hope of the author is to know whether the videobased POE2WE learning model is effective or not applied during a pandemic.

The data analysis used in this research is descriptive technique, which describes the research results that have been obtained. Additionally, it uses a count to calculate the percentage. The formula for determining the percentage quoted from zenius.net (Octavia, 2019) is:

Presentase $(\%)=\frac{\text { jumlah bagian }}{\text { jumlah } \text { keseluruhan }} \times 100 \%$

\section{RESULT AND DISCUSSION}

Research data can be seen in the diagram below:

\section{The effectiveness of the POE2WE model in learning}

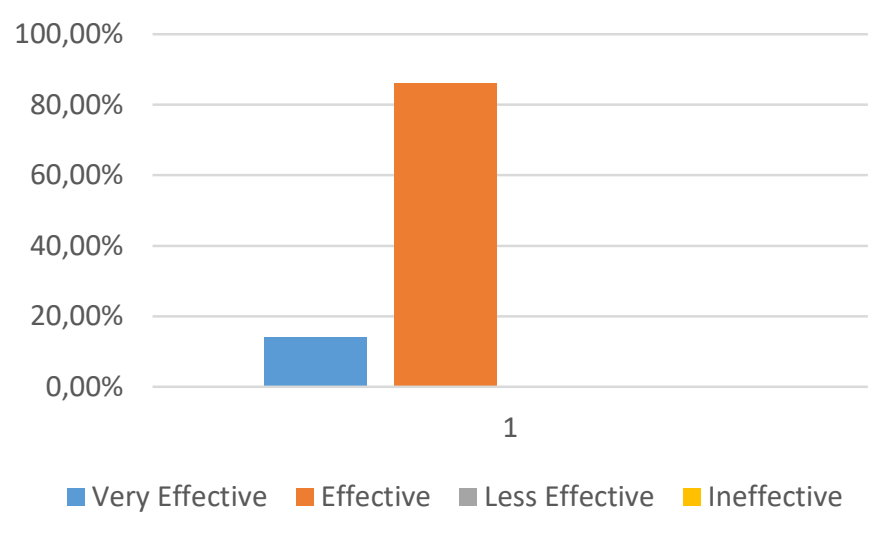

Figure Diagram 1. Effectiveness of the POE2WE Model in Learning

Based on the diagram of the effectiveness of the POE2WE model that has been processed according to equation 2 , there are $14.00 \%$ of correspondents choosing to be very effective, $86.00 \%$ of correspondents choosing to be effective, $0 \%$ of correspondents choosing less effective, and $0 \%$ of correspondents choosing not to be effective.

Based on the responses given by the correspondents, this model is effective because this model is well structured, can hone 4C skills, namely critical thinking, collaborative, creative, and communicative. Besides that, the effectiveness of this model also depends on the learning material as well. 


\section{The effectiveness of using video in online learning}

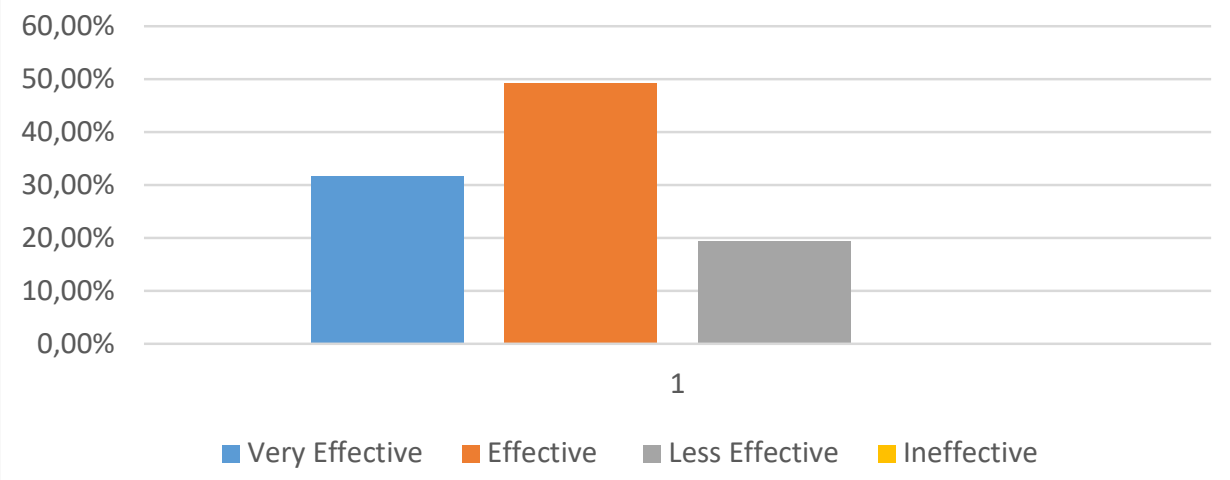

Figure Diagram 2. Effectiveness of Using Video in Online Learning

Based on the diagram of the effectiveness of using video in online learning that has been processed according to equation 2, there are $31.60 \%$ of correspondents who choose to be very effective, $49.10 \%$ of correspondents choose to be effective, $19.30 \%$ of correspondents choose to be less effective, and $0 \%$ of correspondents choose not to be effective.

Based on the responses given by the correspondent, the use of video in online learning is effective because there are audio and visuals that can provide an explanation of the material. In addition, learning videos can be played over and over again if needed. It's just that learning videos are less interactive, so they need other media that can be used as a means of discussion between educators and students such as WhatsApp, telegram, and others.

The effectiveness of the video-based POE2WE model

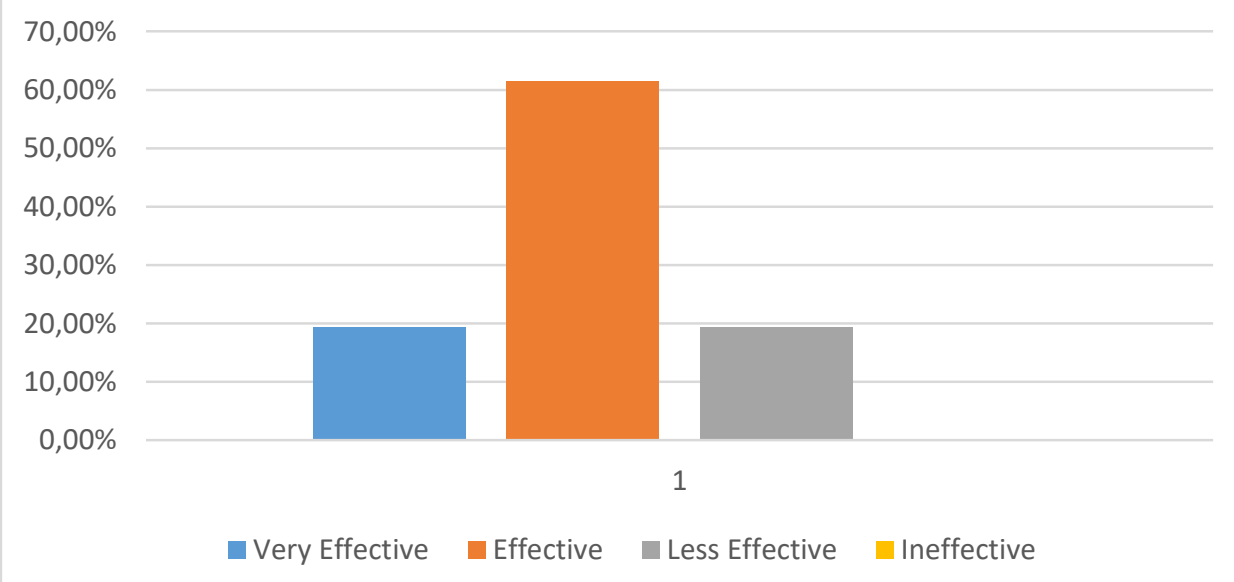

Figure Diagram 3. Effectiveness of Video-Based POE2WE Learning Model 
Based on the diagram of the effectiveness of the video-based POE2WE model that has been processed according to equation 2 there are $19.30 \%$ of correspondents who choose to be very effective, $61 \%$ of correspondents choose to be effective, $19.30 \%$ of correspondents choose to be less effective, and $0 \%$ of correspondents choose not to be effective.

Based on the responses given by the correspondents, this model is effective because the syntax in the POE2WE model is conveyed via video so it is more interesting and solution in this pandemic.

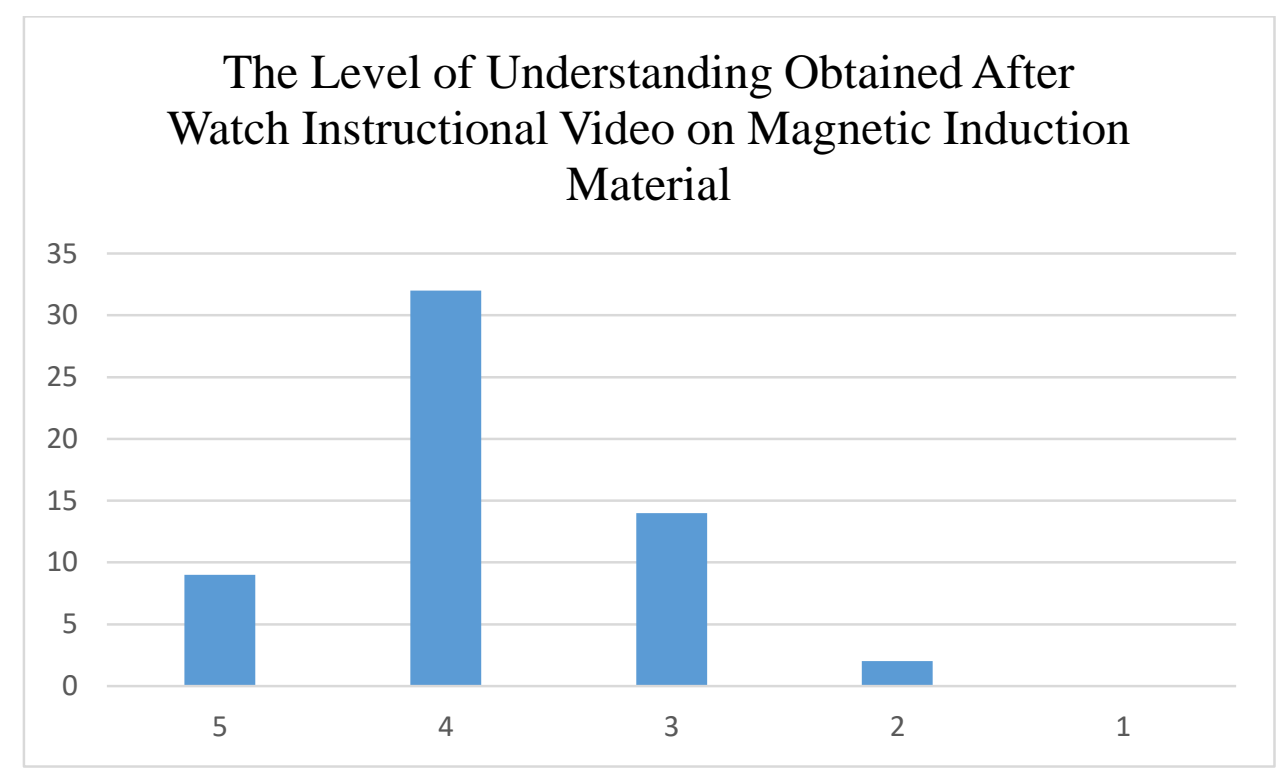

Figure Diagram 4. Level of Understanding on Magnetic Induction Material using VideoBased POE2WE Model

In the diagram above, there is a scale of $1-5$. Where the scale shows the level of understanding of the correspondent to the magnetic induction material delivered using video using the POE2WE model.

Table 2. Level of Understanding Scale

\begin{tabular}{cc}
\hline Scale & Level of Understanding \\
\hline 5 & Very understand \\
4 & Understand \\
3 & Quite understand \\
2 & Not really understand \\
1 & Do not understand \\
\hline
\end{tabular}

The data obtained is processed using equation 2 to produce data in percentage form. There are $15.8 \%$ of correspondents who really understand the material, $56.14 \%$ of correspondents understand, $24.56 \%$ are quite understanding, $3.51 \%$ do not understand, and $0 \%$ do not understand. 


\section{CONCLUSION}

Based on the results obtained from the correspondents, for the highest percentage value of the effectiveness of the POE2WE model in learning is $86.00 \%$ effective, then for the highest percentage value of the effectiveness of using video in online learning is 49.10\% effective, the highest value is for effectiveness. the video based POE2WE model is $61.00 \%$. And the highest percentage for the level of correspondence understanding of magnetic induction material delivered via video using the POE2WE model is $56.14 \%$ understanding. From all these percentages it can be concluded that the video-based learning model on magnetic induction material is effective in this pandemic.

\section{REFERENCES}

Abidah, d. (2020). The Impact of Covid -19 to Indonesian Education and Its Realation to the Phylosophy of "Merdeka Belajar". Studies in Phylosophy of Science and Education, 38-49.

Asnawir, d. (2002). Media Pembelajaran. Jakarta: Ciputat Press.

Dhea, S. P. (2018). Pengembangan Lembar Kerja Peserta Didik Berbasis Predict, Observe, Explain pada Mata Pelajaran Fisika SMP. Jurnal Pembelajaran Fisika, 163-164.

Hosnan. (2014). Pendekatan Sintifik dan Kontekstual dalam Pembelajaran Abad 21. Bogor: Ghalia Indonesia.

Janti, S. (2014). Analisis Validitas dan Reliabilitas dengan Skala Likert Terhadap Pengembangan SI/TI dalam Penentuan Pengambilan Keputusan Penerapan Strategic Planning pada Industri Gamen. Prosiding Seminar Nasional Aplikasi Sains \& Teknologi (SNAST) (pp. A-157). Yogyakarta: Institut Sains \& Teknologi AKPRIND Yogyakarta.

Nana, dkk. (2014). The Development of Predict, Observe, Explain, Elaborate, Write and Evaluate (POE2WE) Learning Model in Physics Learning at Senior Secondary School. Journal of Education and Practice, 59.

Niswatun Aunillah Tarissa, d. (2018). Dampak Blended Learning pada Materi Fluida Dinamis terhadap Haisl Belajar Siswa. Jurnal Pembelajaran Fisika, 117.

Nurdin, E. \&. (2017). Desain Pengembangan Kurikulum Matematika. Pekanbaru: Cahaya Firdaus.

Octavia, B. (2019, Oktober 7). Cara Mudah Menghitung Persen : Rumus, Contoh, Soal dan Pembahasan. Retrieved from Zenius.net: https://www.zenius.net/blog/22697/cara-mudah-menghitung-persen-rumuscontoh-soal-dan-pembahasan

Priyono. (2008). Metode Penelitian Kuantitatif. Surabaya: Zifatama Publishing.

Sugiyono. (2013). Metode Penelitian Pendekatan Kuantitatif, Kualitatif, dan R\&D. Bandung: Alfabeta. 
Suparya, I. K. (2018). Pengaruh Model Pembelajaran Kooperatif Tipe Think, Talk, Write terhadap Hasil Belajar dan Kemampuan Berfikir Kritis pada Pembelajaran IPA. Widyacarya, 20-21. 